\title{
DETERMINAN KESUKSESAN IMPLEMENTASI APLIKASI E-FAKTUR PAJAK
}

Tri Ciptaningsih

STIE YKPN Yogyakarta

E-mail: triciptaningsih@stieykpn.ac.id

\begin{abstract}
This article discuss about the impact of e-tax invoice as the new tax aplication launched by the Directorate General of Taxation. In this article, we will explain about several rules that related to the main topic and Theory Acceptance Model (TAM). Explanation includes several factors which indicated influencing taxpayer behavior in e-tax invoice usage. Those factors are perceived usefulness, perceived ease of use, perceived of Fairness and trust, Norms, attitude, and behavioral intention.
\end{abstract}

Key Words: e-tax invoice, theory acceptance model (TAM), and Tax compliance.

\section{PENDAHULUAN}

Kemajuan teknologi saat ini memberikan dampak yang sangat besar dalam dunia kerja. Kepraktisan dalam proses menjadi isu yang disoroti oleh pihak-pihak yang terkait. Pihak yang terkait tersebut salah satunya adalah Direktorat Jenderal Pajak (DJP). Beberapa tahun belakangan ini, DJP telah banyak mengembangkan aplikasi yang terkait dengan penawaran kemudahan proses pelaporan pajak. Beberapa aplikasi yang telah diluncurkan oleh DJP terkait dengan isu tersebut adalah aplikasi eregistration, e-spt, e-filling, dan e-billing.

E-registration atau Sistem Pendaftaran Wajib Pajak secara Online adalah sistem aplikasi bagian dari Sistem Informasi Perpajakan di lingkungan Direktorat Jenderal Pajak dengan berbasis perangkat keras dan perangkat lunak yang dihubungkan oleh perangkat komunikasi data yang digunakan untuk mengelola proses pendaftaran Wajib Pajak. Sistem ini terbagi dua bagian, yaitu sistem yang dipergunakan oleh Wajib Pajak yang berfungsi sebagai sarana pendaftaran Wajib Pajak secara online dan sistem yang dipergunakan oleh Petugas Pajak yang berfungsi untuk memproses pendaftaran Wajib Pajak.
Aplikasi e-SPT atau disebut dengan Elektronik SPT adalah aplikasi yang dibuat oleh Direktorat Jenderal Pajak yang digunakan oleh Wajib Pajak untuk kemudahan dalam menyampaikan SPT. Kelebihan aplikasi e-SPT adalah sebagai berikut:

1. Penyampaian SPT dapat dilakukan secara cepat dan aman, karena lampiran dalam bentuk media $\mathrm{CD} /$ disket;

2. Data perpajakan terorganisir dengan baik. Sistem aplikasi e-SPT mengorganisasikan data perpajakan perusahaan dengan baik dan sistematis. Penghitungan dilakukan secara cepat dan tepat karena menggunakan sistem komputer;

3. Kemudahan dalam membuat Laporan Pajak;

4. Data yang disampaikan WP selalu lengkap, karena penomoran formulir dengan menggunakan sistem komputer;

5. Menghindari pemborosan penggunaan kertas dan berkurangnya pekerjaanpekerjaan klerikal terkair dengan proses perekaman SPT yang memakan sumber daya yang cukup banyak.

E-Filing adalah suatu cara penyampaian SPT atau pemberitahuan perpanjangan SPT Tahunan yang dilakukan secara on-line yang realtime melalui website Direktorat Jenderal Pajak (www.pajak.go.id) 
atau Penyedia Jasa Aplikasi atau Application Service Provider (ASP). Wajib Pajak dapat menyampaikan SPT atau pemberitahuan perpanjangan SPT Tahunan secara elektronik (e-Filing) melalui sarana:

1. Penyedia Jasa Aplikasi (ASP), berdasarkan Peraturan Direktur Jenderal Pajak Nomor PER-47/PJ/2008 tentang Tata Cara Penyampaian Surat Pemberitahuan dan Penyampaian Pemberitahuan Perpanjangan Surat Pemberitahuan Tahunan Secara Elektronik (e-Filing) melalui Perusahaan Penyedia Jasa Aplikasi (ASP) sebagaimana telah diubah dengan PER$36 / \mathrm{PJ} / 2013$. Jenis surat pemberitahuan yang dapat disampaikan adalah seluruh jenis SPT baik masa maupun tahunan dan juga pemberitahuan perpanjangan SPT tahunan.

2. Situs Pajak, berdasarkan Peraturan Direktur Jenderal Pajak Nomor PER1/PJ/2014 tentang Tata Cara Penyampaian Surat Pemberitahuan Tahunan Pajak Orang Pribadi yang Menggunakan Formulir 1770 S atau 1770 SS secara eFiling. Melalui Situs Pajak (www.pajak.go.id). Jenis surat pemberitahuan yang dapat disampaikan adalah SPT Tahunan PPh Wajib Pajak Orang Pribadi formulir 1770S dan 1770SS.

Untuk menyampaikan SPT atau pemberitahuan perpanjangan SPT Tahunan menggunakan e-Filing, Wajib Pajak dapat:

1. Mengunjungi website Direktorat Jenderal Pajak (www.pajak.go.id) dan klik pada icon $e$-Filing atau langsung mengunjungi alamat efiling.pajak.go.id; atau

2. Mengunjungi halaman penyedia jasa aplikasi (ASP) yang telah ditunjuk oleh Direktorat Jenderal Pajak, yaitu:

- http://www.pajakku.com http://www.laporpajak.com

- http://www.spt.co.id

Wajib Pajak diharuskan memiliki $e$ FIN sebelum dapat menyampaikan SPT atau pemberitahuan perpanjangan SPT Tahunan secara e-Filing. Untuk memperoleh e-FIN, bagi Wajib Pajak yang akan menyampaikan SPT secara e-Filing melalui website Direktorat Jenderal Pajak dapat mengajukan permohonan e-FIN ke KPP terdekat, sedangkan bagi bagi Wajib Pajak yang akan menyampaikan SPT secara e-Filing melalui ASP harus mengajukan permohonan $e$-FIN ke KPP tempat Wajib Pajak terdaftar.

Ditjen Pajak juga menerapkan pembayaran elektronik. Dengan sebutan eBilling, aplikasi ini menawarkan kemudahan pembayaran pajak melalui metode pembayaran elektronik dengan segala kelebihannya: cepat, mudah, nyaman dan fleksibel. Meskipun penerapannya masih dalam tahap ujicoba, namun semua Wajib Pajak yang terdaftar di Kantor Pelayanan Pajak di seluruh Indonesia dapat memanfaatkan fitur layanan ini.

Terkait dengan beberapa aplikasi tersebut di atas, saat ini DJP sedang mengembangkan aplikasi baru yang diberi nama e-Faktur. Aplikasi e-Faktur tersebut ditujukan kepada Pengusaha Kena Pajak dalam memenuhi kewajiban pajaknya yaitu melaporkan SPT PPN. Manfaat dari penggunaan e-Faktur adalah akan mengurangi cost compliance, dimana tidak ada lagi biaya kertas, biaya kirim, print, tenaga kerja verifikasi, pengkodean, dan mengurangi pegawai yang dipekerjakan untuk menangani PPN. Keuntungan juga diperoleh DJP yaitu efisiensi waktu dalam mempercepat proses pada saat pemeriksaan dan pengembalian restitusi.

Pada intinya semua aplikasi tersebut bertujuan untuk memberikan kemudahan bagi pihak-pihak yang bersangkutan. Aplikasi e-Faktur ini muncul menindaklanjuti telah dikeluarkannya Peraturan Menteri Keuangan (PMK) Nomor 151/PMK.011/2013 tanggal 11 November 2013 tentang Tata Cara Pembuatan dan Tata Cara Pembetulan atau Penggantian Faktur Pajak. Faktur pajak terdiri dari Faktur Pajak berbentuk elektronik (e-Faktur Pajak) dan Faktur Pajak berbentuk kertas (hardcopy). EFaktur merupakan Faktur Pajak sebagai bukti pungutan PPN yang dibuat oleh Pengusaha Kena Pajak (PKP) secara elektronik yang tata 
caranya diatur dalam peraturan Direktur Jenderal Pajak. Bentuk e-Faktur Pajak berupa dokumen elektronik yang dapat dicetak dalam bentuk kertas atau dalam bentuk file pdf.

Penerapan e-Faktur Pajak adalah untuk memberikan kemudahan kepada PKP dalam membuat Faktur Pajak dengan menggunakan dan memanfaatkan teknologi informasi, antara lain: (i) tanda tangan basah digantikan dengan tanda tangan elektronik; (ii) e-Faktur Pajak tidak diharuskan untuk dicetak sehingga mengurangi biaya kertas, biaya cetak, dan biaya penyimpanan; (iii) aplikasi e-Faktur Pajak satu kesatuan dengan aplikasi e-SPT, sehingga lebih memudahkan pelaporan SPT Masa PPN; dan (iv) permintaan Nomor Seri Faktur Pajak disediakan secara online via website Direktorat Jenderal Pajak (DJP), sehingga tidak perlu lagi datang ke KPP. Keuntungan yang diperoleh DJP dari aplikasi e-Faktur Pajak adalah meningkatkan validitas Faktur Pajak sekaligus berfungsi sebagai collecting data penyerahan BKP/JKP melalui mekanisme PKP diwajibkan mengirimkan seluruh data keterangan Faktur Pajak ke sistem DJP untuk mendapatkan persetujuan dari DJP (approval). E-Faktur Pajak tanpa persetujuan DJP bukan merupakan Faktur Pajak. Pemberlakuan e-Faktur Pajak dilakukan secara bertahap mulai dari awal bulan Juli 2014 dan berlanjut ke tahun-tahun berikutnya.

Terkait dengan mulai disosialisasikannya e-Faktur Pajak maka pembahasan akan dilakukan pada isu implementasi aplikasi baru tersebut. Teori terkait dengan sistem informasi dan keperilakuan juga akan dibahas kemudian. Teori terkait dengan topik tersebut akan dikaitkan dengan perilaku taat pajak dari Wajib Pajak.

\section{LANDASAN TEORI}

Peran sistem informasi pada masa sekarang dalam menyukseskan program kerja semakin besar. Hal tersebut menarik perhatian banyak peneliti untuk mengamati peran tersebut. Topik-topik penelitian yang dilakukan terkait dengan pengukuran kesuksesan sistem informasi. Salah satunya dilakukan oleh Petter et al. (2008). DeLone dan Mclean (D\&M) mengembangkan modal kesuksesan sistem informasi. Dimensi yang digunakan dalam model tersebut meliputi kualitas sistem, kualitas informasi, kualitas pelayanan, penggunaan, kepuasan pengguna, dan keuntungan bersih. Dimensi tersebut dapat digunakan dalam konteks individu maupun organisasi.

Model D\&M juga banyak digunakan untuk memahami dan mengukur dimensi kesuksesan sistem informasi. Dimensi kesuksesan tersebut adalah sebagai berikut:

1. Kualitas sistem, yaitu terkait dengan karakteristik sistem informasi tersebut. Sebagai contohnya: kemudahan dalam penggunaan (ease of uses), fleksibilitas penggunaan (system flexibility), keandalan sistem (system reliability), dan kemudahan pembelajaran (ease of learning);

2. Kualitas informasi, yaitu terkait dengan karakteristik output sistem sebagai contoh keandalan informasi, kemudahan untuk dipahami, akurasi, kelengkapan, dan ketepatan waktu;

3. Kualitas pelayanan, yaitu kualiatas dukungan yang diterima oleh pengguna dari departemen sistem informasi;

4. Penggunaan sistem, yaitu derajat kemampuan penggunaan sistem misalnya jumlah penggunaan sistem dan tujuan penggunaan;

5. Kepuasan penggunaan, yaitu tingkat kepuasan yang dirasakan oleh pengguna sistem informasi;

6. Keuntungan bersih, terkait dengan seberapa besar suatu sistem informasi mampu memberikan kontribusi kepada individu, kelompok, organisasi, industri, atau negara. Sebagai contoh dalam hal improvisasi pengambilan keputusan, peningkatan penjualan, penurunan biaya, improvisasi profit, efisiensi pasar, kesadaran konsumen, dan lain sebagainya.

Model terkait dengan penggunaan sistem informasi yang sudah dikenal adalah model Technology Acceptance Model (TAM) 
(Davis et al., 1989). Dalam model tersebut dijelaskan bahwa variabel yang mempengaruhi perilaku terhadap intensitas penggunaan dan penggunaa IT adalah anggapan terhadap kegunaan sistem dan kemudahan dalam penggunaannya. Model tersebut juga sudah dibandingkan dengan model Theory of Planned Behavior. Hasil dari perbandingan tersebut menyatakan bahwa penjabaran Theory of Planned Behavior lebih mampu menjelaskan tentang perilaku penggunaan sistem baik dari sisi desain maupun strategi implementasi (Taylor and Todd, 1995).

Paradigma yang digunakan dalam penelitian terkait dengan sistem informasi melibatkan dua disiplin ilmu yaitu terkait dengan ilmu perilaku dan ilmu desain. Ilmu tentang keperilakuan digunakan untuk menjelaskan dan mencoba memprediksi perilaku manusia dalam menggunakan suatu sistem. Ilmu desain digunakan untuk memahami tentang adanya batasan manusia untuk menciptakan suatu sistem baru atau untuk berinovasi (Hevner et al., 2004).

Kim dan Kankanhalli (2009) mencoba menjelaskan penyebab terjadinya penolakan terhadap implementasi suatu sistem. Dari hasil pengamatan diketahui bahwa masalah utama yang dihadapi terletak pada besarnya biaya pemindahan (switching cost) dari sistem lama ke sistem baru. Masalah biaya tersebut memicu terjadinya penolakan sistem baru. Variabel biaya pemindahan (switching cost) memediasi hubungan antara variabel independen (opini kolega dan kepercayaan diri berhasil) terhadap penolakan pengguna. Hal-hal yang dapat mengurangi terjadi penolakan terhadap sistem baru adalah pengetahuan dan kepercayaan terhadap nilai sistem dan dukungan organisasi. Penelitianpenelitian lain yang hampir sama juga dilakukan namun dengan sampel yang berbeda yaitu oleh Venkatesh (2000) dan Davis (1993).

Kaitannya dengan perpajakan dijelaskan oleh Walsh (2012) terdapat beberapa faktor yang mempengaruhi perilaku taat pajak atau sering dikenal dengan kepatuhan pajak. Faktor-faktor tersebut adalah deterrence, norms (both personal and social), fairness and trust (in the tax administration, opportunity and complexity, and the role of government and the broader economic environment).Dari hasil pengujian diketahui bahwa deterrence memiliki dampak terhadap perilaku taat pajak tetapi dikatakan bahwa hal tersebut kurang begitu penting. Deterrence merupakan tindakan penghindaran pajak. Norms terkait dengan keyakinan pada diri seseorang untuk melakukan sesuatu yang benar tidak terikat pada ada atau tidaknya sanksi. Sikap ini dapat dibentuk dari pribadi seseorang atau hasil bentukan dari lingkungan sosial yang melingkupi orang tersebut. Fairness and trust (in the tax administration, opportunity and complexity, and the role of government and the broader economic environment) terkait dengan terkait dengan kepercayaan dan keadilan yang dirasakan oleh seseorang. Ketidakpatuhan pajak dapat disebabkan oleh ketidakpercayaan dan ketidakadilan yang dialami oleh pihak yang dikenai aturan. Barangkali mereka lebih memilih untuk tidak menerima penghargaan atas apa yang mereka perbuat daripada mereka harus diperlakukan tidak adil.

\section{PEMBAHASAN}

Dari penjelasan sebelumnya, dapat diketahui bahwa dalam mengembangkan sistem baru dengan berbagai jenis aplikasi perpajakannya dari DJP perlu melakukan evaluasi terhadap efektivitas dan efisiensi pemberlakukan sistem tersebut. Dari penelusuran literatur diketahui bahwa belum banyak dilakukan penelitian terkait dengan tingkat keberhasilan pelaksanaan aplikasi perpajakan yang selama ini sudah dikembangkan.

Aplikasi terkini yang rencananya sudah mulai diberlakukan oleh DJP adalah e-Faktur Pajak. Pemberlakukan penggunaan e-Faktur ini direncanakan oleh DJP melalui beberapa tahapan, yaitu sebagai berikut:

1. Tahap pertama diberlakukan 1 Juli 2014 untuk PKP tertentu yang dikukuhkan di KPP di lingkungan Kanwil DJP Wajib Pajak Besar, KPP di lingkungan Kanwil 
DJP Jakarta Khusus, dan KPP Madya di Jakarta;

2. Tahap kedua diberlakukan 1 Juli 2015 untuk PKP yang dikukuhkan di KPP di Pulau Jawa dan Bali;

3. Tahap ketiga diberlakukan 1 Juli 2016 untuk PKP secara keseluruhan.

Dalam rangka implementasi tersebut, DJP terlebih dahulu melakukan rangkaian testing aplikasi yang telah dilakukan pada bulan November-Desember 2013 dan piloting yang akan dilakukan pada bulan Januari-Juni 2014. DJP akan menerbitkan Peraturan Direktur Jenderal pajak yang mengatur mengenai tata cara pembuatan eFaktur Pajak. Terkait dengan pelaksanaan eFaktur Pajak tersebut DJP menerbitkan aturan terkait dengan penerbitan faktur pajak yaitu diatur di PER-24/PJ/2012 tentang Bentuk, Ukuran, Tata Cara Pengisian Keterangan, Prosedur Pemberitahuan dalam Rangka Pembuatan, Tata Cara Pembetulan atau Penggantian dan Tata Cara Pembatalan Faktur Pajak yang memuat beberapa perubahan yang mendasar di bidang Pajak Pertambahan Nilai, terutama terkait dengan tata cara pemberian nomor seri faktur pajak. Dampak dari peraturan tersebut adalah berpindahnya kewenangan penomoran faktur pajak yang sebelumnya merupakan domain Wajib Pajak kini menjadi domain DJP.

Langkah pertama yang ditempuh PKP adalah mengajukan terlebih dahulu permohonan Kode Aktivasi dan Password secara langsung ke KPP dimana Pengusaha Kena Pajak tersebut dikukuhkan. Kode Aktivasi dan password akan diberikan oleh Direktorat Jenderal Pajak kepada Pengusaha Kena Pajak yang telah memenuhi syarat, sebagai berikut:

1. Pengusaha Kena Pajak telah dilakukan Registrasi Ulang Pengusaha Kena Pajak oleh Kantor Pelayanan Pajak tempat PKP terdaftar berdasarkan Peraturan Direktur Jenderal Pajak Nomor PER05/PJ/2012 dan perubahannya dan laporan hasil registrasi ulang verifikasi menyatakan PKP tetap dikukuhkan; atau

2. Pengusaha Kena Pajak telah dilakukan verifikasi berdasarkan Peraturan Menteri
Keuangan

Nomor

73/PMK.03/2012 tentang Jangka Waktu

Pendaftaran dan Pelaporan Kegiatan Usaha, Tata Cara Pendaftaran, Pemberian, Dan Penghapusan Nomor Pokok Wajib Pajak, Serta Pengukuhan dan Pencabutan Pengukuhan Pengusaha Kena Pajak.

Ketentuan-ketentuan baru yang diatur dalam Peraturan tersebut adalah:

1. Kode dan nomor seri Faktur Pajak terdiri dari 16 (enam belas) digit yaitu: 2(dua) digit kode transaksi, 1 (satu) digit kode status, dan 13 (tiga belas) digit nomor seri Faktur Pajak;

2. Nomor seri Faktur Pajak diberikan oleh DJP melalui permohonan dengan instrumen pengaman berupa kode aktivasi dan password;

3. Identitas Penjual dan Pembeli, terutama alamat harus diisi dengan alamat sebenarnya atau sesungguhnya;

4. Jenis Barang Kena Pajak atau Jasa kena Pajak harus diisi dengan keterangan yang sebenarnya atau sesungguhnya;

5. Pemberitahuan PKP/pejabat/pegawai penandatangan Faktur Pajak, harus dilampiri dengan fotokopi kartu identitas yang sah dan dilegalisasi pejabat yang berwenang;

6. PKP yang tidak menggunakan nomor seri Faktur Pajak dari DJP atau menggunakan nomor seri Faktur Pajak ganda akan menyebabkan Faktur Pajak yang diterbitkan merupakan Faktur Pajak tidak lengkap;

7. Faktur Pajak tidak lengkap akan menyebabkan PKP pembeli tidak dapat mengkreditkan sebagai Pajak Masukan dan PKP Penjual dikenakan sanksi sesuai dengan ketentuan yang berlaku.

Terkait dengan aturan di atas menuntut adanya kesiapan dari sisi Wajib Pajak untuk dapat segera melaksanakan aturan tersebut. Wajib pajak diharapkan dapat segera beradapatasi dengan sistem baru tersebut yaitu e-Faktur Pajak. Apalagi mengingat sanksi yang diberikan tegas. Oleh sebab itu, pendekatan untuk mengukur derajat kemampuan Wajib Pajak untuk mengikuti 
aturan tersebut menjadi penting untuk terhadap penerimaan Wajib Pajak terhadap dilakukan.

Model baru yang dikembangkan merupakan pengembangan dari berbagai model yang telah ditemukan dan diuji oleh para peneliti sebelumnya yaitu adanya uji

sistem e-Faktur Pajak dan faktor-faktor apa saja yang mempengaruhinya. Apabila digambarkan pada sebuah bagan dapat disajikan sebagai berikut ini:

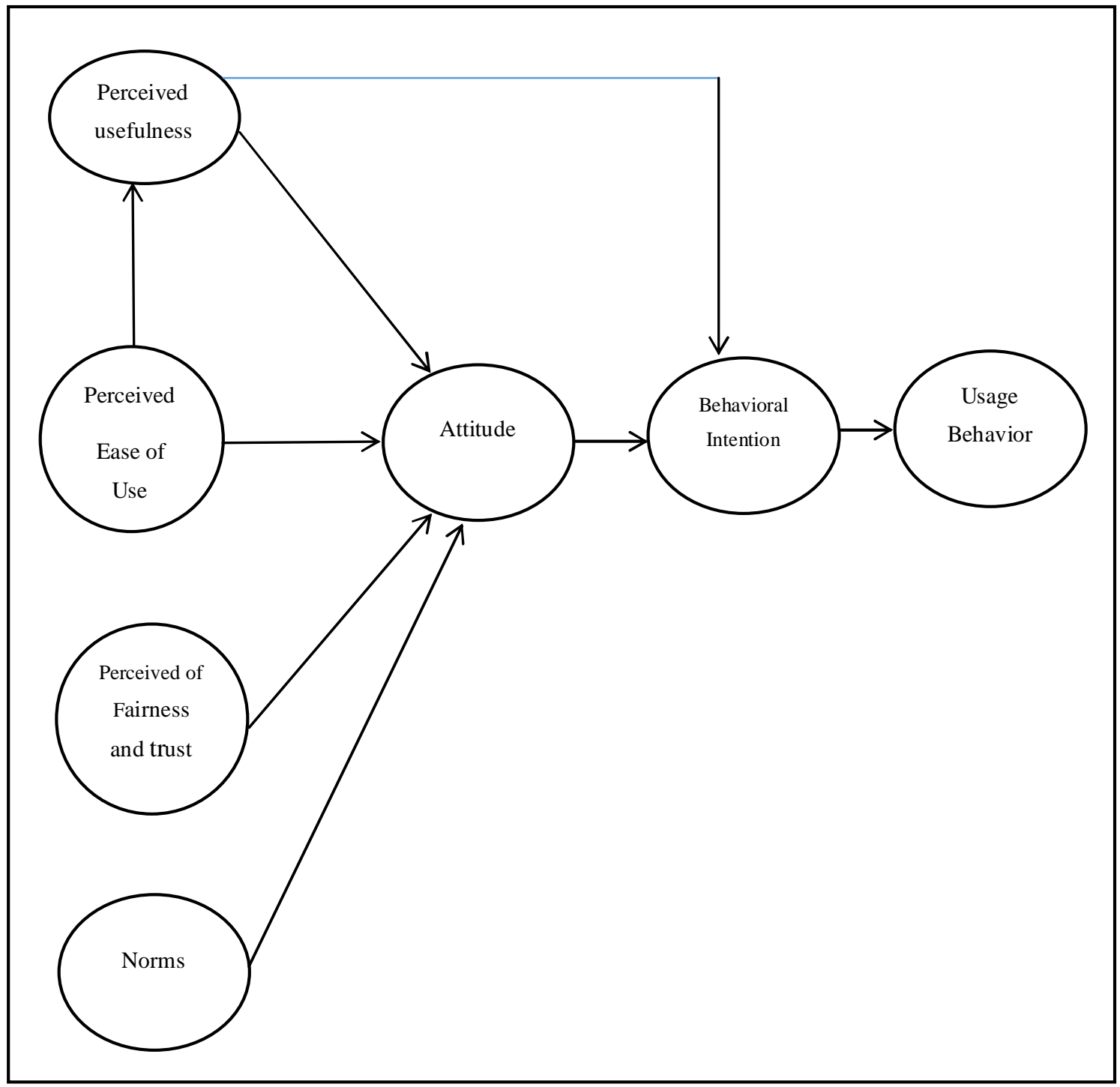

Dari gambar di atas, dapat diuji secara empiris tingkat keberhasilan program eFaktur Pajak DJP tentunya setelah program tersebut mulai dijalankan dan memperoleh feedback dari Wajib Pajak.

\section{KESIMPULAN}

Dari pembahasan sebelumnya, dapat ditarik kesimpulan sebagai berikut:

1. Pengembangan aplikasi perpajakan melibatkan isu keperilakuan yaitu perilaku Wajib Pajak dalam merespon sistem baru yang muncul.

2. Dalam mengembangkan sistem baru, DJP perlu memperhatikan faktor-faktor yang mempengaruhi keberhasilan implementasi sistem tersebut. Faktor-faktor yang mempengaruhi antara lain pandangan WP terhadap kegunaan sistem, kemudahan penggunaan, kepercayaan dan keadilan, norma, perilaku WP.

3. Apabila antara DJP dengan WP telah mengatasi masalah yang muncul dalam 
tahapan implementasi aplikasi e-Faktur tersebut semestinya tujuan yang diharapkan oleh fiskus (DJP) dapat tercapai.

\section{DAFTAR PUSTAKA}

Davis, Fred D. (1989). Perceived Usefulness, Perceived Ease of Use, and User Acceptance of Information Technology. MIS Quarterly. Vol. 13 No. 3 pp. 319340.

Davis, Fred D. (1993). User Acceptance of Information Technology: Systems Characteristic, User Perceptions and Behavioral Impact. Int. J. Man-Machine Studies. 38. 475-487.

Hevner, Alan R., Salvatore T. March., dan Jinsoo Park. (2004). Design Science in Information Systems Research. MIS Quarterly. Vol. 28 No. 1 pp. 75-105

Kim, Hee-Woong dan Atreyi Kankanhallli. (2009). Investigating User Resistance to Information Systems Implementation: A Status Quo Bias Perspective. MIS Quarterly. Vol. 33 No. 3 pp. 567-582.

Petter, S., William DeLone, dan Ephraim McLean. (2008). Measuring Information System Success: Models, Dimensions, measures, and Interrelationships. European Journal of Information Systems. 17. 236-263.

Taylor, Shirley dan Peter A. Todd (1995). Information Systems Research. Institute for Operations Research and the Management Sciences. 6:2.

Venkatesh, Viswanath. (2000). Determinants of Perceived Ease of Uses: Integrating
Control, Intrinsic Motivation, and Emotion into the Technology Acceptance Model. Information Systems Research. Vol. 11 No. 4.

Walsh, Keith. (2012). Understanding Taxpayer Behaviour-New Opportunities for Tax Administration. Office of the Revenue Commissioners.

Peraturan Direktur

Jenderal Pajak Nomor PER-47/PJ/2008 tentang Tata Cara Penyampaian Surat Pemberitahuan dan Penyampaian Pemberitahuan Perpanjangan Surat Pemberitahuan Tahunan Secara Elektronik (e-Filing) melalui Perusahaan Penyedia Jasa Aplikasi (ASP).

Peraturan Direktur

Jenderal Pajak Nomor PER-36/PJ/2013 tentang Tata Cara Penyampaian Surat Pemberitahuan dan Penyampaian Pemberitahuan Perpanjangan Surat Pemberitahuan Tahunan Secara Elektronik (e-Filing) melalui Perusahaan Penyedia Jasa Aplikasi (ASP).

Peraturan Direktur

Jenderal Pajak Nomor PER-1/PJ/2014 tentang Tata Cara Penyampaian Surat Pemberitahuan Tahunan Pajak Orang Pribadi yang Menggunakan Formulir 1770S atau 1770SS secara e-Filing.

$\begin{array}{llr} & \begin{array}{c}\text { Peraturan } \\ \text { Keuangan }\end{array} \text { Menteri } \\ \text { 151/PMK.011/2013 tanggal } & 11 \\ \text { November } 2013 \text { tentang Tata } & \text { Cara } \\ \text { Pembuatan dan Tata Cara Pembetulan } \\ \text { atau Penggantian Faktur Pajak. }\end{array}$

